Novoa, F. J., T. A. Altamirano, C. Bonacic, K. Martin, and J. T. Ibarra. 2021. Fire regimes shape biodiversity: responses of avian guilds to burned forests in Andean temperate ecosystems of southern Chile. Avian Conservation and Ecology 16(2):22. https://doi.org/10.5751/ACE-01999-160222 Copyright (C) 2021 by the author(s). Published here under license by the Resilience Alliance.

Research Paper

\title{
Fire regimes shape biodiversity: responses of avian guilds to burned forests in Andean temperate ecosystems of southern Chile
}

\author{
Fernando J. Novoa ${ }^{1,2}$, Tomás A. Altamirano ${ }^{1,2,3}$ (D) , Cristián Bonacic ${ }^{2}$, Kathy Martin ${ }^{3,4}$ and José Tomás Ibarra ${ }^{1,5}$ (D) \\ ${ }^{1}$ ECOS (Ecosystem-Complexity-Society) Co-Laboratory, Center for Local Development (CEDEL), and Center for Intercultural and \\ Indigenous Research (CIIR), Villarrica Campus, Pontificia Universidad Católica de Chile, Villarrica, Chile, ${ }^{2}$ Fauna Australis \\ Wildlife Laboratory, Department of Ecosystems and Environment, Faculty of Agriculture and Forest Sciences, Pontificia \\ Universidad Católica de Chile, Santiago, Chile, ${ }^{3}$ Department of Forest and Conservation Sciences, University of British Columbia, \\ Vancouver, BC, Canada, ${ }^{4}$ Environment and Climate Change Canada, Pacific Wildlife Research Centre, Vancouver, BC, Canada, \\ ${ }^{5}$ Department of Ecosystems and Environment, Faculty of Agriculture and Forest Sciences and Center of Applied Ecology and \\ Sustainability (CAPES), Pontificia Universidad Católica de Chile, Santiago, Chile
}

\begin{abstract}
Fire regimes of forests, i.e., time interval, frequency, extent, and severity of fire events, influence structural changes in the vegetation, and thus shape the composition of avian communities. We studied the diversity of avian guilds in sites with different fire regimes (unburned, burned 2002, burned 2015, and burned 2002 and 2015), testing both the "intermediate disturbance" and "vertical vegetation structure" hypotheses, in globally threatened temperate forests in Chile. From 2016 to 2018 , we quantified habitat attributes (160 plots) and estimated avian richness and density (160 point counts). The site that was burned once in 2015 showed the highest density of standing dead trees at $96.5 \%$ higher than the unburned/control site, whereas the site that burned twice showed the lowest density of live trees, lowest average diameter at breast height of trees (DBH), and smallest volume of coarse woody debris. Overall, we recorded 35 avian species with the highest richness $(n=24$ species $)$ in the site that was burned once in 2002 . We found that, 16 years after a site was burned, the avian community composition became relatively similar to the unburned site. The density of most avian guilds decreased in burned sites but granivores, shrub users, and migrants showed positive responses. Understory users, foliage users, and resident species showed negative responses to burned sites. These responses were strongly related to fire-driven changes in habitat attributes, supporting both of our tested hypotheses. Given that increasing levels of disturbance from fire are anticipated, future management of temperate forest biodiversity should consider that specific species and guilds will depend on remnant habitat attributes in burned sites.
\end{abstract}

\section{Le régime des incendies façonne la biodiversité : réactions des guildes aviaires aux forêts brûlées dans les écosystèmes andins tempérés du sud du Chili}

RESUME_. Le régime des incendies de forêt, c'est-à-dire l'intervalle de temps, la fréquence, l'étendue et la sévérité des incendies, influent sur les changements structurels de la végétation et donc sur la composition des communautés aviaires. Nous avons étudié la diversité des guildes aviaires dans des sites présentant différents régimes d'incendie (non brûlé, brûlé en 2002, brûlé en 2015, et brûlé en 2002 et 2015), en testant à la fois les hypothèses de «perturbation intermédiaire » et de « structure verticale de la végétation » dans des forêts tempérées du Chili menacées à l'échelle planétaire. De 2016 à 2018, nous avons mesuré les caractéristiques de l'habitat (160 parcelles) et calculé la richesse et la densité aviaire (160 dénombrements par points d'écoute). Le site qui a brûlé une fois en 2015 présentait la plus forte densité d'arbres morts sur pied, soit $96,5 \%$ de plus que le site non brûlé/témoin, tandis que le site qui a brûlé deux fois présentait la plus faible densité d'arbres vivants, le plus faible diamètre moyen à hauteur de poitrine des arbres (DHP) et le plus petit volume de débris ligneux grossiers. Nous avons noté 35 espèces aviaires dans l'ensemble, et la plus grande richesse ( $\mathrm{n}=24$ espèces) se trouvait dans le site qui a brûlé une fois en 2002. Nous avons constaté que, 16 ans après qu'un site ait brûlé, la composition de la communauté aviaire était redevenue relativement similaire à celle du site non brûlé. La densité de la plupart des guildes aviaires a diminué dans les sites brûlés, mais les granivores, les utilisateurs d'arbustes et les migrateurs ont eu des réactions positives. Les utilisateurs du sous-étage, les utilisateurs du feuillage et les espèces résidentes ont réagi négativement aux sites brûlés. Ces réactions étaient fortement liées aux changements des attributs de l'habitat induits par le feu, résultat qui soutient nos deux hypothèses. Étant donné qu'on prévoit une augmentation des perturbations par le feu, la gestion future de la biodiversité des forêts tempérées devrait tenir compte du fait que des espèces et des guildes spécifiques dépendront des attributs de l'habitat restant dans les sites brûlés.

Key Words: bird community; disturbance; fire history; habitat legacies; 


\section{INTRODUCTION}

Fires are critical drivers of the dynamics of several forest ecosystems because they modify the vertical and horizontal stand structure, often with long-lasting effects on the habitat of forestdwelling species (Flannigan et al. 2009, Stephens et al. 2015, Fuentes-Ramirez et al. 2018). Fires can, therefore, be a major cause of habitat loss because $4 \%$ of the earth's land surface is burned annually (30-46 million $\mathrm{km}^{2}$; Randerson et al. 2012). Fire is a natural disturbance of ecosystem processes in a number of ecoregions, e.g., boreal forests and savannah ecosystems, whereas in others the frequency of natural fires is intrinsically low, e.g., tropical Southeast Asia (Bond et al. 2005). Fire regime refers to the dynamic behavior of fires occurring over an extended period of time (Brown 1995). These regimes are being altered in many ecosystems worldwide by anthropogenic causes, including climate change (Harvey et al. 2016, Prichard et al. 2017). The effects of fire regimes on biodiversity will be influenced by the number of times a site has been burned, the time elapsed since the last fire, the extent of the fire, and its severity, i.e., the quantity of loss of organic matter above and below ground (Keeley 2009, Krebs et al. 2010, Chavardès 2014). Thus, fire regimes shape the structural complexity of post-fire habitats and may model the evolutionary adaptations of wildlife species in fire-prone ecosystems (Watson et al. 2012, Drapeau et al. 2016).

According to the intermediate disturbance hypothesis, habitat specialist species will predominate numerically in the community in undisturbed habitats (Connell 1978). In highly disturbed ecosystems, habitat generalist species, able to resist or adapt to the new environmental conditions, will persist (DeBano et al. 1998, Jaksic and Fariña 2015). In ecosystems with slight to moderate levels of disturbance, diversity will be maximized because both specialists and generalists may coexist (Connell 1978). Although some theoretical and empirical studies have rejected this hypothesis (e.g., Fox 2013), it still provides an important conceptual framework for examining the diversity found across habitat disturbance gradients (Maclean et al. 2003, Catford et al. 2012). The vertical vegetation structure hypothesis (MacArthur and MacArthur 1961, Recher 1969) can be tested in tandem with the intermediate disturbance hypothesis because the former may allow examining the mechanisms that underlie diversity patterns across disturbance gradients. The vertical vegetation structure hypothesis predicts that forest biodiversity will be greater in vertically complex stands than in structurally simple habitats (Ibarra and Martin 2015a, Caviedes and Ibarra 2017). Avian community composition will vary differentially in forests with recent fires compared to older fires based on the trajectories of recovery of the system (Vierling and Lentile 2008, Clavero et al. 2011, Latif et al. 2016). In recently burned areas, some species benefit from the availability of new resources, e.g., aerial foragers and some woodpeckers (Kotliar et al. 2002), whereas other species will avoid burned habitats, e.g., Black-eared Miner (Manorina melanotis; Clarke et al. 2005). For example, nest density of the Black-backed Woodpecker (Picoides arcticus) was higher in the year following a fire compared to previous years, probably on account of the temporal increase in bark and woodboring beetles, which typically colonize recently burned forests (Nappi and Drapeau 2009). Over time, however, avian community composition changes, as has been shown for western boreal forests in Canada, where snag-dependent bird species decreased and shrub-breeding species increased after 25 years post-fire (Hannon and Drapeau 2005). After a fire, an initial period of higher bird species diversity can occur, followed by a decline when dead trees fall (Bock et al. 1978). Avian responses to burned sites may depend on the extent to which the ecological succession, and associated structural changes in the vegetation, gradually provide or cease to provide their life history requirements (Pons and Clavero 2010).

A functional guild is "a group of species that exploit the same class of environmental resources in a similar way" (Simberloff and Dayan 1991:115), and thus are expected to respond similarly to a given disturbance. The habitat attributes that form the structural complexity of the vegetation are essential if certain functional guilds of birds are to persist in altered sites (Wunderle 1997). Therefore, the effects of fire on habitat attributes may be especially important, because many birds respond strongly to these features in their post-fire habitat (Ganey et al. 1996). For example, the presence of habitat legacies, such as standing dead trees, coarse woody debris, and understory, allows the foraging and reproduction of certain guilds, such as large-tree users and understory users, in a post-fire site (Morissette et al. 2002, Whelan et al. 2002). In subtropical semi-arid ecosystems of Argentina, forests converted from structurally complex stands to dense grasslands showed an avian community dominated by habitat generalists and a significant reduction of nectarivores, foliage users, and bark insectivores because of the lack of trees and shrubs (Albanesi et al. 2013). When some pre-disturbance vegetation structure survives a fire, certain guilds of birds can remain or should be able to approximate to their pre-fire densities as compared to other guilds (Franklin et al. 2000, Whelan et al. 2002).

In the face of climate change, fires are increasing in frequency in many ecoregions globally (Lindenmayer et al. 2008, Cochrane and Barber 2009, Driscoll et al. 2010). It is crucial to assess the effects of fire regimes on biodiversity, particularly in globally threatened ecosystems such as temperate forests of South America (Clavero et al. 2011). Temperate forests of Chile and Argentina have a relatively low richness of birds (51 species), but $41 \%$ of these are endemic (Vuilleumier 1985, Altamirano et al. 2017). Here, Araucaria (Araucaria araucana) forests have been shaped by a mixed-severity and low frequency natural fire regime, including surface and crown fires after volcanic eruptions, with widespread high-severity fires being infrequent (Arroyo et al. 1995, González et al. 2005). Araucaria forest cover, estimated to be 500,000 ha in the 1550 s, has been reduced by almost $50 \%$ on account of intensive logging and fires (Lara et al. 1999). Mostly post-1880, the frequency of human-set fires in Araucaria forests has increased, resulting in severe effects on vegetation and soil (González et al. 2011, Perfetti-Bolaño et al. 2013, Zuñiga et al. 2021). Increases in burning, mainly associated with forest clearing, grazing, and logging activities of new settlers, could have strongly affected Araucaria landscapes, altering the vegetation mosaic and the fire regime (González et al. 2009). Although it is suspected that fires can have important consequences for forestdwelling biodiversity, little is known about how avian communities respond to the increasing frequency of fires in these ecosystems.

In this study, we examine the responses of avian diversity (richness and density) of functional guilds and habitat attributes in sites with different fire regimes (number of times a site has been burned 
and time elapsed since the last fire) in Araucaria forests of southern Chile. We evaluate the relationship between different habitat attributes and avian density, predicting that (1) slightly disturbed (i.e., sites burned once more than a decade ago) and moderately disturbed (i.e., sites burned once recently) habitats, will show greater diversity of species compared to unburned and highly disturbed (i.e., sites burned twice, with a recent fire event; intermediate disturbance hypothesis) habitats, and (2) avian diversity will be greater in vertically complex types of vegetation and lower in structurally simple habitats (vertical vegetation structure Hypothesis) because the former offers greater foraging and breeding opportunities for birds inhabiting these forests.

\section{METHODS}

\section{Study area}

The study was conducted in the Araucarias Biosphere Reserve (ABR) in the Andean zone of La Araucanía Region, southern Chile $\left(38^{\circ}-39^{\circ} \mathrm{S}, 71^{\circ} \mathrm{W}\right.$; UNESCO 2010$)$. We conducted the study in areas adjacent to the China Muerta National Reserve $(11,170$ ha, including 3700 ha burned in 2015), the Malleco National Reserve (16,625 ha, 9090 ha burned in 2002), and the Tolhuaca National Park (6408 ha, 3845 burned in 2002 and approximately 4000 ha burned in 2015). The unburned area has not suffered disturbances in the last decades (Fuentes-Ramírez et al. 2020). The fire in the Malleco National Reserve was caused by lightning, whereas all the others were caused by human accidental ignition. The climate is temperate with a short dry season (January-March) and an average annual rainfall of $1945 \mathrm{~mm}$ (Luebert and Pliscoff 2006). Elevation in the ABR ranges from 200 to $3747 \mathrm{~m}$ above sea level (m a.s.1.) with forests up to $\sim 1700 \mathrm{~m}$ a.s.l. The Araucaria forest type is found at over $\sim 1000 \mathrm{~m}$ a.s.l. (Donoso 1993). These forests are dominated by Araucaria araucana and species of the Nothofagus genus (Fuentes-Ramirez et al. 2018, Urrutia-Estrada et al. 2018), with Chusquea spp. dominating the understory (González et al. 2009).

We selected four treatments (hereafter, sites) according to their fire frequency and levels of disturbance: (A) control (unburned; undisturbed); (B) burned once in 2002 (hereafter, "burned 2002"; slightly disturbed because it was burned once and it experienced a relatively long time for recovery; sampled 16 years post-fire); (C) burned once in 2015 (hereafter, "burned 2015"; moderately disturbed because it was burned once and it experienced a relatively short time for recovery; sampled two years post-fire); and (D) burned twice, in 2002 and 2015 (hereafter, "burned 2002/2015"; highly disturbed because it was burned twice and it experienced a relatively short time for recovery; sampled three years after the last fire; Fig. 1). These four sites were between 1014 and $1469 \mathrm{~m}$ a.s.l. and separated by at least $5 \mathrm{~km}$ from the next closest site. In the three burned sites, we examined the severity of fire according to assessments of damage conducted by the National Forestry Service(CONAF 2017). The three sites suffered high-severity fires, i.e., crown fires with $>90 \%$ of trees and understory vegetation charred, in the surveyed areas. Furthermore, there was a dense layer of ash in the soil (up to 30 $\mathrm{cm}$ in depth) and large holes in the ground caused by tree stumps that were completely carbonized through below-ground combustion with evidence of tree carbonization, root damage, and significant loss of shrub vegetation (CONAF 2017, Zúñiga et al. 2021).
Fig. 1. Study sites in three protected areas affected by forest fires in the Araucarias Biosphere Reserve, Andean zone of the La Araucanía Region $\left(38^{\circ}-39^{\circ}\right)$, Chile. Colored points show the specific location of sites: control (green), "burned 2002" (yellow), "burned 2015" (blue), and "burned 2002/2015" (red).

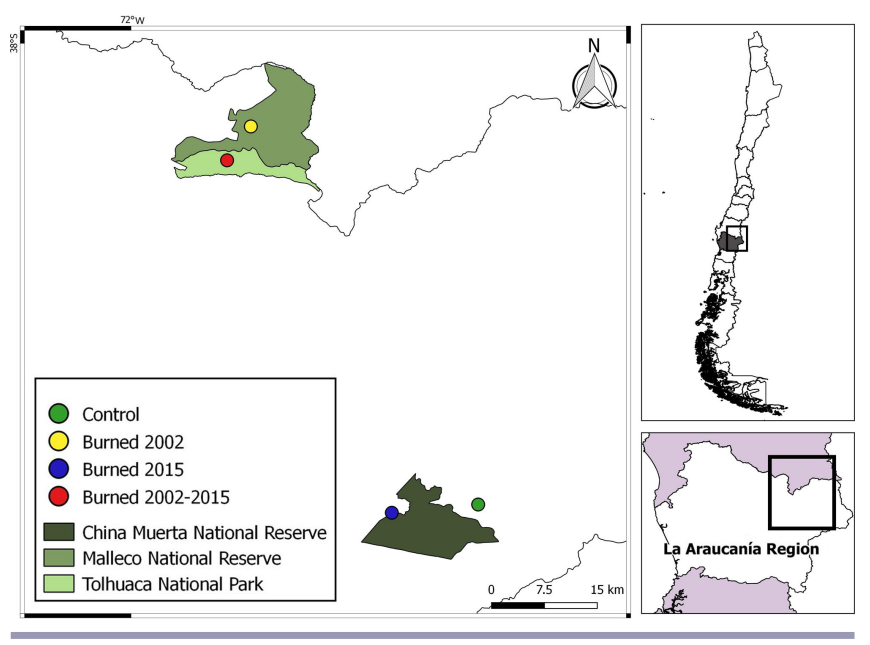

\section{Habitat sampling}

At each of our four sites, we systematically established 40 vegetation plots separated by at least $150 \mathrm{~m}$ (radius of $11.2 \mathrm{~m}$; 0.04 ha; Total $n=160$ plots; Ibarra and Martin 2015b). In each plot, we measured the following habitat attributes: density of live and standing dead trees (number/ha), diameter at breast height (DBH, in cm) of each tree, cover of bamboo understory (\%), cover of coarse woody debris $(\%)$, cover of intermediate canopy $(\%)$, cover of upper canopy $(\%)$, and volume of coarse woody debris ( $\mathrm{m}^{3}$; Ibarra et al. 2014, Caviedes and Ibarra 2017).

\section{Bird sampling}

In each site, we established 40 point counts at the center of each vegetation plot (Total $n=160$ surveys). During two breeding seasons (December-February; Ralph et al. 1996), we sampled the control site and the "burned 2015" site in 2016-2017 and the "burned 2002" and "burned 2002/2015" sites in 2017-2018. Each station was surveyed once in our four sites. Each point count lasted six minutes during which all the birds seen and/or heard within a radius of $50 \mathrm{~m}$ we recorded and grouped into two distance intervals (0-25 m and 26-50 m; Bibby et al. 2000, Ibarra and Martin 2015b). For bird species with a low detection rate, we used call playbacks at odd-numbered point counts in order to avoid duplicate counting of species in neighboring points, i.e., 20 point counts with playback per site. Each call had a duration of $30 \mathrm{~s}$ for each species, followed by $30 \mathrm{~s}$ of silence between species' calls (total of $15 \mathrm{~min}$ of survey time for stations with playbacks). The order of playbacks was Magellanic Tapaculo (Scytalopus magellanicus), Chucao Tapaculo (Scelorchilus rubecula), Blackthroated Huet-huet (Pteroptochos tarnii), Des Murs's Wiretail (Sylviorthorhynchus desmursii), Ochre-flanked Tapaculo (Eugralla paradoxa), Magellanic Woodpecker (Campephilus magellanicus), Chilean Flicker (Colaptes pitius), Striped Woodpecker (Dryobates lignarius), and White-throated Treerunner (Pygarrhichas albogularis). The use of playback was considered as an additional covariate (dummy) for species detectability. 
Table 1. Bird species and guilds used to evaluate their response to wildfires in the Andean temperate forest of southern Chile.

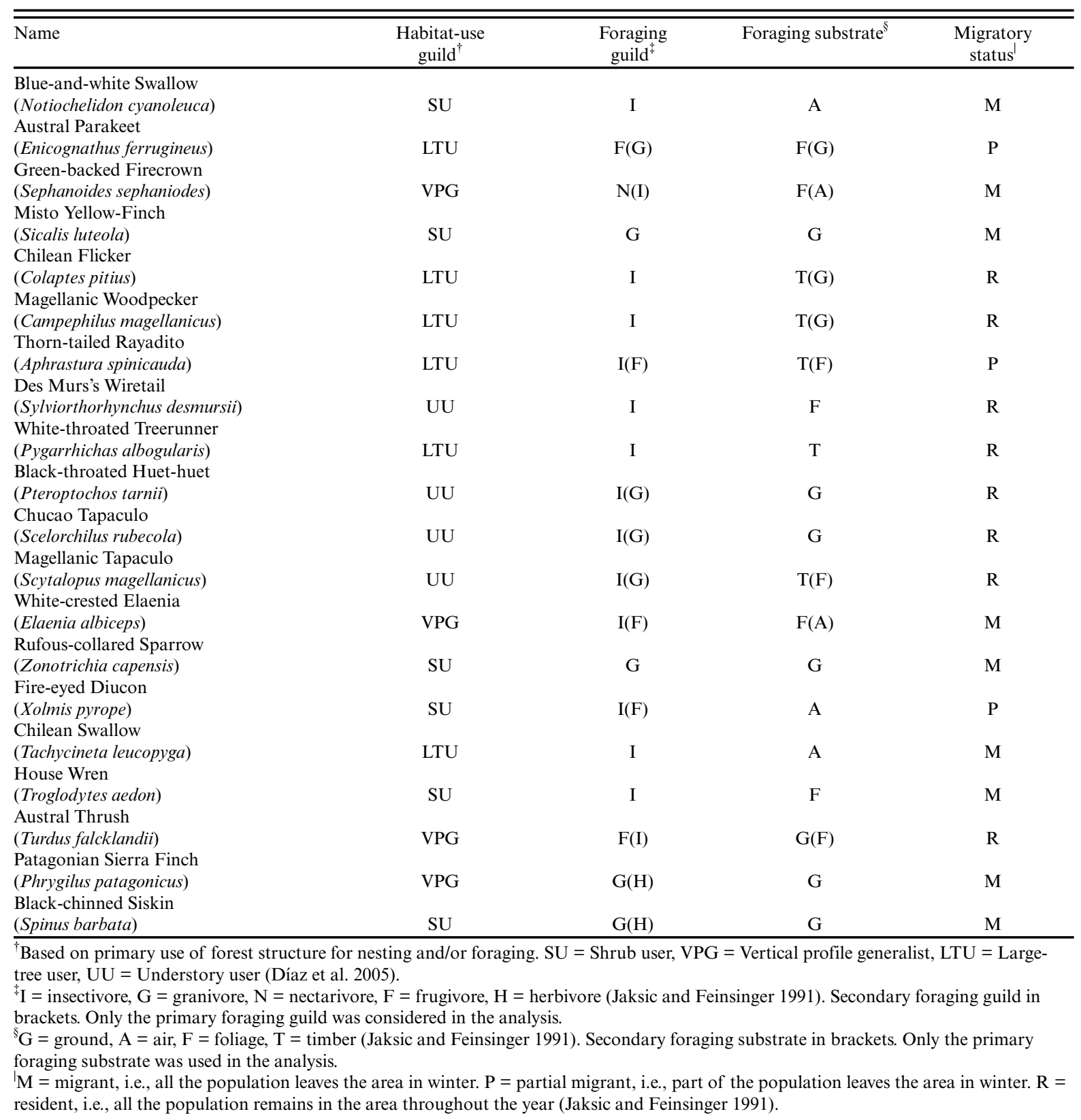

We conducted the counts during the first four hours after sunrise (between 6:00 and 10:00 AM). We recorded temperature $\left({ }^{\circ} \mathrm{C}\right)$, humidity $(\%)$, and wind speed $(\mathrm{m} / \mathrm{s})$ at each point count, using a portable meteorological unit (Kestrel 4200, Kestrel-meters, Birmingham, MI). We used a portable bluetooth speaker for playback calls.

\section{Data analysis}

Habitat attributes, and avian detectability and density We used one-way ANOVA with Tukey's post-hoc tests to analyze differences of habitat attributes between sites with different fire regimes. To estimate detectability $(p)$ and density $(D)$, we used only bird species recorded more than 10 times $(n=20$ species, Table 1) at all counting points. Estimates of bird density vary depending on the detectability of the species and these may be affected by the distance of the observer $(25-50 \mathrm{~m})$ and other specific sampling covariates, including temporal factors and weather conditions (Buckland et al. 2001, Royle et al. 2004, Ibarra et al. 2014). To estimate $p$ and $D$ for each species at each point count, we used mixed multinomial Poisson models (Royle et al. 2004). Maximum likelihood methods were used in the $R$ Unmarked program (Chandler 2014) in R (R Development Core Team 2019). 
Table 2. Candidate covariates for estimating bird detectability and density in burned sites and the control site in Chile's Andean temperate forest between 2016 and 2018.

\begin{tabular}{|c|c|}
\hline Type of covariate (abbreviation) & Description \\
\hline $\begin{array}{l}\text { Temporal and climate covariates: } \\
\text { 1.1 } \text { Season }^{\dagger} \\
\text { 1.2 } \text { Time }^{\dagger} \\
\text { 1.3 } \text { Date }^{\dagger} \\
\text { 1.4 } \text { Noise }^{\dagger} \\
\text { 1.5 Temperature (Temp) } \\
\text { 1.6 Humidity (Hum) } \\
\text { 1.7 Wind speed (Wind) } \\
\text { 1.8 Cloud cover (Cloud) } \\
\text { 1.9 Playback (Play) }\end{array}$ & $\begin{array}{l}\text { 1: } 2016-2017 \text { season, } 2: 2017-2018 \text { season } \\
\text { Minutes elapsed since } 6: 30 \mathrm{AM} \\
\text { Julian date } \\
\text { Environmental noise. } 0 \text { : silent, } 1 \text { : significant (i.e., noise of wind and/or river) } \\
\text { Temperature }\left({ }^{\circ} \mathrm{C}\right) \\
\text { Relative humidity }(0-100 \%) \\
\text { Average speed }(\mathrm{m} / \mathrm{s}) \\
\text { Sky cloud cover. } 0: \text { no cloud, } 0.5 \text { : partially cloudy, } 1 \text { : totally cloudy } \\
\text { Reproduction of song of less conspicuous birds after } 6 \text { silent minutes of counting. } 0 \\
\text { without playback, } 1 \text { : with playback }\end{array}$ \\
\hline
\end{tabular}

Environmental covariates for density:

2.1 Understory cover (Under_covgral) ${ }^{\dagger}$

2.2 Bamboo cover (Under_bam)

2.3 Coarse woody debris (Cwd)

Proportion of ground covered by understory (between $0.5 \mathrm{~m}$ and $3 \mathrm{~m}$ in height), estimated at center of plot

Proportion of ground covered by bamboo (Chusquea spp), estimated at center of plot Proportion of ground covered by coarse woody debris with diameter $\geq 7.5 \mathrm{~cm}$, estimated at center of plot

Proportion of sky covered by intermediate canopy (between 3 and $5 \mathrm{~m}$ in height), estimated at center of plot

2.4 Intermediate canopy cover (Int_canopy)

Proportion of sky covered by upper canopy ( $>5 \mathrm{~m}$ in height), estimated at center of

2.5 Upper canopy cover (Up_canopy)

2.6 Average diameter at breast height $(\mathrm{DBH})^{\dagger}$ 2.7 Density of live trees (Tree_ha) plot

Trees measured with $\mathrm{DBH} \geq 12.5 \mathrm{~cm}$

Density per ha of all live trees with $\mathrm{DBH} \geq 12.5 \mathrm{~cm}$

Density per ha of standing dead trees with $\mathrm{DBH} \geq 12.5 \mathrm{~cm}$

Calculation based on length and diameter of each segment with diameter $\geq 7.5 \mathrm{~cm}$, crossing the transect of $11.2 \mathrm{~m}$ in length, and/or standing dead trees with height $\leq 1.3 \mathrm{~m}$ (in N-S direction)

${ }^{\dagger}$ Covariates selected for testing temporal and environmental associations in birds in burned sites and control site after reducing collinearity.

Before estimating $p$ and $D$, we evaluated collinearity to reduce the number of covariates. Collinear covariates $(r>0.6)$ were eliminated, retaining only those predicted to be the most biologically influential for each species (Table 2; Dainese and Poldini 2012, Ibarra and Martin 2015a). For each species, we first estimated $p$ using temporal and weather covariates identified using AIC (Anderson et al. 2015). The models $\leq 2$ AIC value units were considered as the competitive models and thus we averaged the estimates of $p$ from these competitive models $(\triangle \mathrm{AIC}<2$; Burnham and Anderson 2002). For each species, a step-wise covariate selection procedure was used (without parameterizing $D$ ) and each model was then classified by AIC, selecting the bestranked models to continue modeling $D$ (Ibarra and Martin 2015a). We estimated $D$ according to habitat attributes and, to obtain the best models of $D$, we created a set of candidate models based on the model weights (wi) and the accuracy of the estimated coefficients, using AIC. Models within 2 AIC units of the top model were considered as the competitive set of best-supported models (Burnham and Anderson 2002). An average range of 17 to 24 models of $D$ was evaluated for the 20 species.

\section{Functional guild responses to burned sites}

Avian species were classified into guilds according to habitat use, foraging mode, foraging substrate and migratory status (Table 1). The resultant guilds were related to the use of resources relevant to the ecosystem function, i.e., quantity, type, and temporality of the resource used and the strategies of each species to obtain the resources (Table 2). Some of these guilds have been associated with the vulnerability of the species to habitat alteration in temperate forests (Díaz et al. 2005, Cofre et al. 2007, Ibarra and Martin 2015b). The response of the guilds to the different burned conditions was compared using generalized linear mixed models (GLMMs). These models describe the relationship between a response variable and a set of explanatory covariates (fixed effects) compiled in units aggregated at different levels (random effects). We tested the fixed effect of the control, "burned 2002," "burned 2015," and "burned 2002/2015" sites on the observed richness and estimated density of avian guilds (response variables). The sampling season (2016-2017, 2017-2018) was used as a random effect. For these analyses, the lme4 (Bates et al. 2015), nlme (Pinheiro et al. 2017), and AICcmodavg (Mazerolle 2017) statistical packages were used in R (R Development Core Team 2019).

\section{RESULTS}

\section{Habitat attributes}

The control site had the highest density of live trees $(90 \%$ higher than the "burned 2002/2015" site; Table 3) and the highest volume of coarse woody debris ( $92 \%$ higher than the "burned 2002/2015" site). The "burned 2002" site had the largest average tree size (DBH; 76\% higher than the "burned 2002/2015" site) and the highest percentage of understory cover $(71.6 \%$ higher than the "burned 2015" site). The "burned 2015" site had the highest density of standing dead trees ( $96.5 \%$ higher than the control site). Out of all the sites, the "burned 2002/2015" site had the lowest 
Table 3. Measures of habitat attributes for burned areas of the Andean temperate forest of southern Chile. The average of the values obtained and the standard deviation are shown $(n=160$ plots). Values with an asterisk indicate significant differences between each site calculated using one-way ANOVA with Tukey's post-hoc tests.

\begin{tabular}{|c|c|c|c|c|c|}
\hline Habitat attributes & Control & Burned 2002 & Burned 2015 & Burned 2002/2015 & $p$ \\
\hline Tree density $\left(\mathrm{N}^{\circ} / \mathrm{Ha}\right)$ & $417.6 \pm 218.6^{*}$ & $214.5 \pm 144.2 *$ & $355.4 \pm 247$ & $43.2 \pm 90^{*}$ & $3.06 \mathrm{e}-16$ \\
\hline Snag density $\left(\mathrm{N}^{\circ} / \mathrm{Ha}\right)$ & $10.2 \pm 20.6$ & $148.5 \pm 105.3^{*}$ & $292.6 \pm 188.5^{*}$ & $43.2 \pm 90$ & $2.2 \mathrm{e}-16$ \\
\hline Diameter at breast height $(\mathrm{DBH} ; \mathrm{cm})$ & $37.3 \pm 13.7^{*}$ & $43.5 \pm 24.6$ & $34.8 \pm 15.2$ & $10.4 \pm 14.4^{*}$ & $2.23 \mathrm{e}-14$ \\
\hline Coarse woody debris volume $\left(\mathrm{m}^{3}\right)$ & $1.2 \pm 1.8^{*}$ & $0.3 \pm 0.4^{*}$ & $1 \pm 1.1$ & $0.1 \pm 0.4^{*}$ & $2.38 \mathrm{e}-06$ \\
\hline Understory cover $(\%)$ & $39.0 \pm 28.4^{*}$ & $64.1 \pm 23.6^{*}$ & $18.2 \pm 18.3^{*}$ & $46.3 \pm 27.9$ & $1.6 \mathrm{e}-12$ \\
\hline
\end{tabular}

density of live trees, the lowest average $\mathrm{DBH}$, and the smallest volume of coarse woody debris (Table 3 ).

\section{Richness of bird community}

We recorded 35 bird species (Fig. 2.1), corresponding to nine orders and 19 families. Most species belonged to the Passeriformes order $(71.4 \% ; n=25)$. The Furnariidae and Tyrannidae were the most represented families, with seven and five species, respectively. The "burned 2002" site had the greatest avian richness $(n=24)$, whereas the "burned 2015" site had the lowest avian richness (n $=19$ ). We recorded eight species exclusively in the burned sites, whereas nine species were recorded in all sites (Appendix 1). We recorded only two species, the Chilean Pigeon (Patagioenas araucana) and the Patagonian Tyrant (Colorhamphus parvirostris), exclusively in the control site.

Fig. 2. Values predicted by generalized linear mixed models (GLMMs) of species richness and bird density (birds/ha) for each point count of species in the four sampling sites: control (green), "burned 2002" (yellow), "burned 2015" (blue), and "burned 2002/2015" (red). Different letters indicate significant differences $(p<0.05)$ among treatments. The box indicates groups of numerical data through their quartiles, midline is the median of the data for each site, and the whiskers are the parallel lines that show the variability outside the upper and lower quartiles. Individual points that are beyond the whiskers indicate outliers that are numerically distant from the rest of the data.
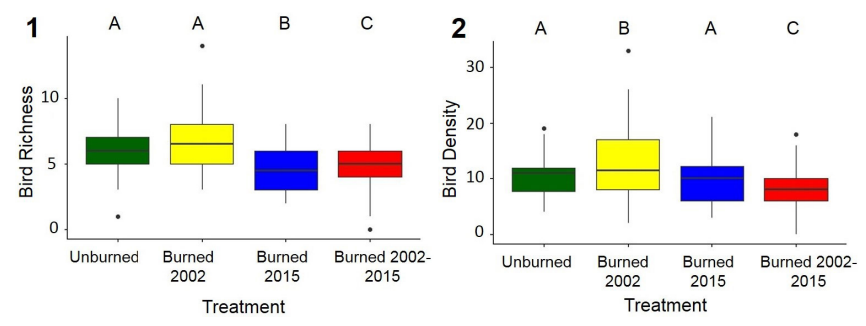

\section{Species detectability and density}

The detectability of 12 of the 20 species was associated with temporal or climate covariates (Table 4). Cloud cover was the covariate associated with more avian species $(n=5)$. The estimated density of 17 species was associated with some environmental covariates (Table 4). For 13 species, we found a positive association with $\mathrm{DBH}$, whereas the only negative association was for the Rufous-collared Sparrow (Zonotrichia capensis). The Magellanic
Woodpecker (Campephilus magellanicus) showed the highest influence of DBH on its estimated density (Table 4). On the other hand, avian density differed among burned sites. The "burned 2002" site showed the highest bird density, which was 5.2 times higher than in the "burned 2002/2015" site, which showed the lowest densities (Fig. 2.2).

\section{Habitat-use guilds}

The density of shrub users (SU; Fig. 3.1) was highest in the "burned 2002/2015" site (11.2 times higher than in the control site), whereas the highest density of vertical profile generalists (VPG; Fig. 3.2) was observed in the "burned 2015" site (7.5 times higher than in the control site and the "burned 2002/2015" site). In the case of large-tree users (LTU; Fig. 2.3), density was highest in the "burned 2015" site (10.75 times higher than in the "burned 2002/2015" site). The lowest density of understory users (UU; Fig. 3.4) was in the "burned 2002/2015" site (Appendix 2).

Fig. 3. Values predicted by generalized linear mixed models (GLMMs) of density (birds/ha) for each point count of the habitat-use guild for (1) shrub-user birds, (2) vertical profile generalist birds, (3) large-tree users, and (4) understory users, in the four sampling sites: control (green), "burned 2002" (yellow), "burned 2015" (blue), and "burned 2002/2015" (red). Different letters indicate significant differences $(p<0.05)$ among treatments. The box indicates groups of numerical data through their quartiles, midline is the median of the data for each site, and the whiskers are the parallel lines that show the variability outside the upper and lower quartiles.
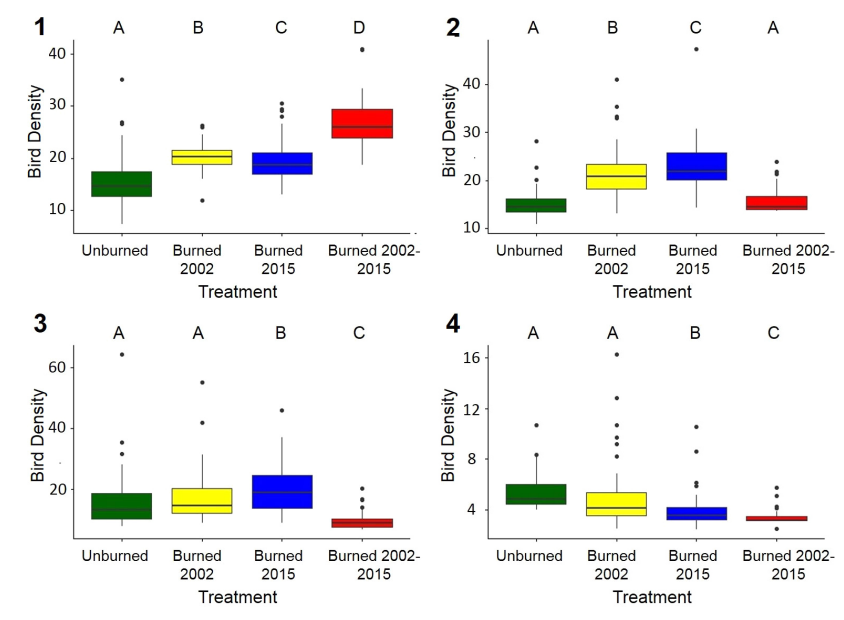
Table 4. Covariates associated with the estimated detectability $(p)$ and density $(D)$ of bird species in the Andean temperate forest of Chile, according to the selection of models based on the Akaike information criterion (AIC). Estimates of the parameters are shown and values in brackets () indicate the standard error. The positive (+) and negative $(-)$ signs indicate the direction of the relationship. See Table 1 for species scientific names.

\begin{tabular}{|c|c|c|c|c|c|c|c|c|c|c|c|c|c|c|}
\hline \multirow[b]{2}{*}{ Name } & \multicolumn{7}{|c|}{ Detectability $(p)$} & \multirow[b]{2}{*}{ Cloud } & \multirow[b]{2}{*}{ Play } & \multicolumn{3}{|c|}{ Density $(D)$} & \multirow[b]{2}{*}{ Cwd_vol } & \multirow[b]{2}{*}{ Under_covgral } \\
\hline & Season & Time & Date & Noise & Temp & Hum & Wind & & & $\mathrm{DBH}$ & Tree_ha & Snag_ha & & \\
\hline $\begin{array}{l}\text { Green-backed } \\
\text { Firecrown }\end{array}$ & & & & & & & & & & $\begin{array}{c}0.013 \\
(0.006)\end{array}$ & & & & \\
\hline Chilean Flicker & & & & & $\begin{array}{l}-0.865 \\
(0.077)\end{array}$ & & $\begin{array}{c}7.691 \\
(0.569)\end{array}$ & & & $\begin{array}{l}0.023 \\
(0.01)\end{array}$ & & & & \\
\hline $\begin{array}{l}\text { Magellanic } \\
\text { Woodpecker }\end{array}$ & & & & & & & & & & $\begin{array}{c}0.043 \\
(0.015)\end{array}$ & & & & \\
\hline Thorn-tailed Rayadito & $\begin{array}{l}-0.234 \\
(0.101)\end{array}$ & & & & & & & $\begin{array}{l}-1.292 \\
(0.503)\end{array}$ & & $\begin{array}{c}0.011 \\
(0.004)\end{array}$ & & & & \\
\hline Des Murs's Wiretail & & & & & & & & $\begin{array}{l}-1.148 \\
(0.508)\end{array}$ & $\begin{array}{c}0.458 \\
(0.187)\end{array}$ & & & & & \\
\hline White-throated & & & & & & & & & & 0.018 & & & & \\
\hline Treerunner & & & & & & & & & & $(0.008)$ & & & & \\
\hline $\begin{array}{l}\text { Black-throated Huet- } \\
\text { huet }\end{array}$ & & & & & & & & & & $\begin{array}{c}0.028 \\
(0.009)\end{array}$ & & & & \\
\hline Chucao Tapaculo & & & & & & & & & & $\begin{array}{c}0.023 \\
(0.007)\end{array}$ & & & & \\
\hline Magellanic Tapaculo & & & & & & & & & & $\begin{array}{c}0.017 \\
(0.005)\end{array}$ & & & & \\
\hline White-crested Elaenia & & & & & $\begin{array}{l}-0.013 \\
(0.005)\end{array}$ & & & $\begin{array}{l}-0.235 \\
(0.068)\end{array}$ & & $\begin{array}{c}0.008 \\
(0.002)\end{array}$ & $\begin{array}{c}0.001 \\
(0.0002)\end{array}$ & $\begin{array}{l}-0.0009 \\
(0.0003)\end{array}$ & $\begin{array}{l}-0.091 \\
(0.046)\end{array}$ & $\begin{array}{c}0.006 \\
(0.002)\end{array}$ \\
\hline Fire-eyed Diucon & & & & & & & & & & & & & & \\
\hline Chilean Swallow & $\begin{array}{c}0.609 \\
(0.218)\end{array}$ & & & & & & & & & & & & & $\begin{array}{c}0.017 \\
(0.007)\end{array}$ \\
\hline $\begin{array}{l}\text { Blue-and-white } \\
\text { Swallow }\end{array}$ & & $\begin{array}{c}0.008 \\
(0.003)\end{array}$ & & & & & & & & $\begin{array}{c}0.018 \\
(0.006)\end{array}$ & & & & $\begin{array}{l}-0.025 \\
(0.007)\end{array}$ \\
\hline House Wren & & & $\begin{array}{l}0.0008 \\
(0.0003)\end{array}$ & & & & & & & & $\begin{array}{c}-0.002 \\
(0.0005)\end{array}$ & $\begin{array}{c}0.002 \\
(0.0006)\end{array}$ & & \\
\hline Austral Thrush & & & & & & & & $\begin{array}{l}-0.484 \\
(0.194)\end{array}$ & & $\begin{array}{c}0.017 \\
(0.005)\end{array}$ & & $\begin{array}{l}0.002 \\
(0.001)\end{array}$ & & $\begin{array}{l}0.0099 \\
(0.005)\end{array}$ \\
\hline $\begin{array}{l}\text { Rufous-collared } \\
\text { Sparrow }\end{array}$ & & & & & & & & & & $\begin{array}{l}-0.033 \\
(0.007)\end{array}$ & $\begin{array}{l}-0.016 \\
(0.006)\end{array}$ & $\begin{array}{c}0.013 \\
(0.006)\end{array}$ & & $\begin{array}{c}0.012 \\
(0.004)\end{array}$ \\
\hline $\begin{array}{l}\text { Patagonian Sierra } \\
\text { Finch }\end{array}$ & & & $\begin{array}{c}0.002 \\
(0.0006)\end{array}$ & & & & & & & & & & & \\
\hline Misto Yellow-Finch & & & $\begin{array}{l}-0.098 \\
(0.023)\end{array}$ & & $\begin{array}{c}0.037 \\
(0.016)\end{array}$ & & & & & & & & & $\begin{array}{c}0.01 \\
(0.004)\end{array}$ \\
\hline Black-chinned Siskin & & & $\begin{array}{l}-0.002 \\
(0.0004)\end{array}$ & & & & $\begin{array}{l}0.326 \\
(0.15)\end{array}$ & & & $\begin{array}{c}0.009 \\
(0.003)\end{array}$ & $\begin{array}{c}-0.004 \\
(0.0008)\end{array}$ & $\begin{array}{c}0.006 \\
(0.0009)\end{array}$ & & $\begin{array}{c}-0.01 \\
(0.003)\end{array}$ \\
\hline Austral Parakeet & & $\begin{array}{c}-0.004 \\
(0.0008)\end{array}$ & & & & & & $\begin{array}{c}0.383 \\
(0.121)\end{array}$ & & $\begin{array}{c}0.022 \\
(0.004)\end{array}$ & $\begin{array}{c}-0.002 \\
(0.0006)\end{array}$ & $\begin{array}{c}0.003 \\
(0.0008)\end{array}$ & & \\
\hline
\end{tabular}

Covariates: Season, Time, Date (Julian, day 1 = Jan 1), Noise, Temp: temperature, Hum: humidity, Wind: wind speed; Cloud: cloud cover; Play: playback; DBH: average diameter at breast height; Tree_ha: density of live trees; Snag_ha: density of dead trees; Cwd_vol: volume of coarse woody debris; Under_covgral: general understory cover.

\section{Foraging guilds}

The highest density of insectivorous birds (I; Fig. 4.1) was observed in the control site (six times higher than in the "burned 2002/2015" site), whereas the density of granivores (G; Fig. 4.2) was highest in the "burned 2002/2015" site (11.67 times higher than in the control site). In the case of nectarivores (N; Fig. 4.3), density was highest in the "burned 2002" site (1.2 times higher than in the control site), whereas frugivore densities (F; Fig. 4.4) were highest in the "burned 2002" site (1.9 times higher than in the control site; Appendix 2).

\section{Foraging substrate guilds}

The highest density of birds that use the ground as their foraging substrate (G; Fig. 5.1) was observed in the "burned 2002/2015" site (10.5 times higher than in the control site), whereas aerial foragers (A; Fig. 5.2), had the highest densities in the "burned 2015 " site ( 0.3 times higher than in the control site) and was lowest in the "burned 2002/2015" site (control site was 3.85 times higher). The density of foliage gleaners (F; Fig. 5.3) was highest in the "burned 2002" site (9.7 times higher than in the control site). In the case of birds that use timber or bark (T; Fig. 5.4), density was highest in the control site (4.1 times higher than in the "burned 2002/2015" site; Appendix 2).

\section{Migratory status guilds}

The density of migrant birds (M; Fig. 6.1) was highest in the "burned 2002/2015" site (12.1 times higher than in the control site), whereas, for partial migrant birds (P; Fig. 6.2), it was highest in the "burned 2015" site (5.4 times higher than in the control site). The highest density of resident birds (R; Fig. 6.3) was observed in the control site (4.3 times higher than in the "burned 2002/2015" site; Appendix 2).

\section{DISCUSSION}

\section{Response of the overall avian community to fire regimes}

This study reveals important differences in the bird community responses to fire regimes in globally threatened Araucaria forests in the Andes of southern Chile. The results show variation in the 
Fig. 4. Values predicted by generalized linear mixed models (GLMMs) of density (birds/ha) for each point count of the avian foraging guild for (1) insectivores, (2) granivores, (3) nectarivores, and (4) frugivores in the four sampling sites: control (green), "burned 2002" (yellow), "burned 2015" (blue), and "burned 2002/2015" (red). Different letters indicate significant differences $(\mathrm{p}<0.05)$ among treatments. The box indicates groups of numerical data through their quartiles, midline is the median of the data for each site, and the whiskers are the parallel lines that show the variability outside the upper and lower quartiles. Individual points that are beyond the whiskers indicate outliers that are numerically distant from the rest of the data.
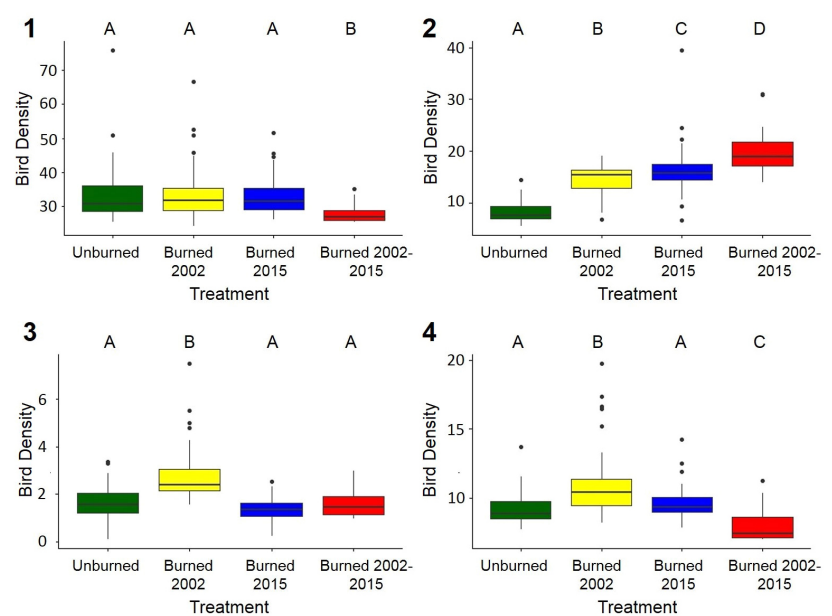

response of overall avian richness and density of different avian guilds, depending on the number of fires and the time interval between each fire of the surveyed sites.

We found that time since the fire likely influenced differences in avian community composition of each site (bird abundance and richness increased with stand age and vegetation growth), with results similar to those of Moreira et al. (2003) and Clavero et al. (2011). These two studies found that avian composition in a burned forest depends heavily on time since the fire, which is related to the progress of vegetation succession with an associated gradual increase in structural complexity. In a pine (Pinus halepensis) forest in Israel, avian diversity increased from forests burned one and five years previously (Izhaki and Adar 1997). This study also found that several species avoided burned sites in the first two years after the fire and only recolonized three to five years post-fire. The response of these species was strongly linked to vegetation succession over time in the burned forests (Izhaki and Adar 1997).

The highest richness and density of birds were observed in the "burned 2002" site, probably because of the partial recovery of the vegetation since the fire disturbance 16 years ago. These results partially support the intermediate disturbance hypothesis according to which there will be a greater diversity of species in slightly disturbed habitats (Connell 1978, Hidasi-Neto et al.
Fig. 5. Values predicted by generalized linear mixed models (GLMMs) of density (birds/ha) for each point count the foraging substrate guild for (1) ground, (2) air, (3) foliage, and (4) timber in the four sampling sites: control (green), "burned 2002" (yellow), "burned 2015" (blue), and "burned 2002/2015" (red). Different letters indicate significant differences $(\mathrm{p}<0.05)$ among treatments. The box indicates groups of numerical data through their quartiles, midline is the median of the data for each site, and the whiskers are the parallel lines that show the variability outside the upper and lower quartiles.
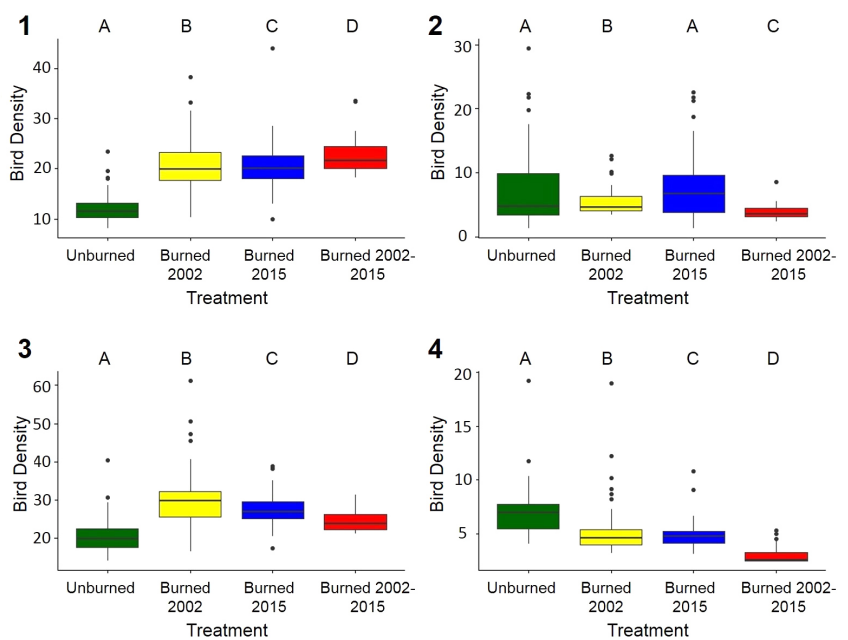

2012). The unpredictable nature of most fires, e.g., timing, location, and severity, often maintains landscape heterogeneity by creating a variety of successional stages; avian communities will vary among successional stages and forest types (Morissette et al. 2002). In the same Araucaria-Nothofagus forests sampled in this study, some native plants characteristic of the understory, such as Chusquea culeou, Gaultheria poeppigii, and Alstroemeria aurea, were able to re-sprout abundantly in burned areas (UrrutiaEstrada et al. 2018). In addition, $A$. araucana trees can reproduce from seeds or by re-sprouting after a fire (González et al. 2010, Fuentes-Ramírez et al. 2019), whereas $N$. pumilio reproduces only from obligate seed germination (Fuentes-Ramirez et al. 2018). This recovery, together with the mixture of early succession species and habitat legacies in the "burned 2002" site (slightly disturbed), could explain the greater richness of avian species we recorded in areas burned 16 years ago (Shiel and Burslem 2003).

The vertical vegetation structure hypothesis (MacArthur and MacArthur 1961, Recher 1969) was tested in tandem with the intermediate disturbance hypothesis in order to examine whether sites with greater structural complexity, e.g., relatively higher density of standing dead trees and a dense understory (Caviedes and Ibarra 2017), host higher avian diversity than structurally simpler habitats. Our results are in accordance with previous studies conducted in other forest ecosystems, e.g., Brazilian Amazon and Australian forest, where the lowest avian richness was found in forests with greater frequency of fires (Peres et al. 
Fig. 6. Values estimated by generalized linear mixed models (GLMMs) of density (birds/ha) for each point count of migratory status species for (1) migrant birds, (2) partial migrant birds, and (3) resident birds in the four sampling sites: control (green), "burned 2002" (yellow), "burned 2015" (blue), and "burned 2002/2015" (red). Different letters indicate significant differences (p < 0.05) among treatments. The box indicates groups of numerical data through their quartiles, midline is the median of the data for each site, and the whiskers are the parallel lines that show the variability outside the upper and lower quartiles.
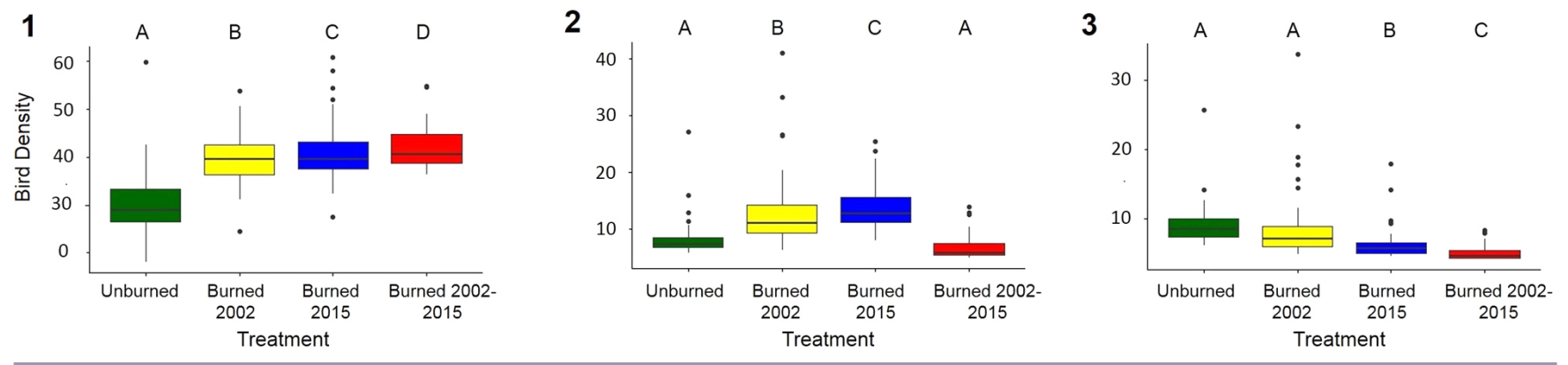

2003, Barlow and Peres 2004, Lindenmayer et al. 2008). The latter can be explained by a reduction of the structural complexity of forest systems after fires (White et al. 2016).

\section{Response of functional guilds to fire regimes}

Avian guilds responded differently to the fire regimes of the different sites in our study. The density of all shrub user species was higher in all burned sites. This is consistent with the findings of Fontaine et al. (2009) and Stephens et al. (2015), who observed that shrub users benefited from reduced tree cover and an increase in shrub volume up to nine years after the fire in a mixed broadleaved and coniferous forest in southwestern Oregon.

A higher density of large-tree users and vertical profile generalist birds was observed in the "burned 2002" (slightly disturbed) and "burned 2015" (moderately disturbed) sites, probably on account of the change in vegetation structure, e.g., increase of snags, which creates new foraging and nesting opportunities for the species in these guilds (Morissette et al. 2002). For example, large-tree users usually depend on decayed trees for nesting (Altamirano et al. 2017). The low density of large-tree users and vertical profile generalists in the twice burned site (highly disturbed) is likely associated with the low density of live and standing dead trees that are essential for several species from these two guilds (PerfettiBolaño et al. 2013). For birds that use old-growth trees as their foraging substrate, the highest density was observed in the control site (undisturbed). The rapid decline of these birds, such as the Magellanic Woodpecker and Chilean Flicker, in disturbed sites may be explained chiefly by the fact that these species require larger areas of forest and the presence of large decaying trees for feeding (Ibarra and Martin 2015a, Vergara et al. 2016). Smucker et al. (2005) suggested that the response of a species to a fire is observed, in many cases, years after the event. For example, an excavator like the Northern Flicker (Colaptes auratus) showed an increase in density starting the third year after the fire (Smucker et al. 2005) but Wiebe (2014) found that the number of individuals increased in the year following the fire.

The low density of understory users in recently burned sites may reflect their association with a dense understory, promoting a negative response when the lower vegetation stratum is damaged by a fire (Reid et al. 2004). In addition, birds from the
Rhinocryptidae family can use fallen trunks for refuge and reproduction (Venegas et al. 2009, Altamirano et al. 2017). The latter may explain the lowest density of these species in the twiceburned site in line with its lack of understory cover and refuge. However, we found that, as the understory recovers as reported for the "burned 2002" site (slightly disturbed), understory users can begin to recolonize an area in three to five years post-fire (Venegas et al. 2009). Many species of insectivorous birds (bark searching, arboreal, and terrestrial) avoid open areas and treefall gaps in burned forest-dominated landscapes (Barlow and Peres 2004). Kreisel and Stein (1999) observed that, after a fire in a coniferous forest in Washington, there was a decrease in the number of beetles under the bark and a decline in the abundance of four woodpecker species. In the Amazon, Barlow et al. (2002) found that both insectivores and bark-user birds were significantly less abundant in burned forests compared to unburned forests.

The greater density of granivorous and ground-foraging birds in burned areas could be attributed to greater access to seeds. Fire generally makes for an increase in the availability of some foraging resources, e.g., seeds of the herbaceous plants that colonize these sites (Milesi et al. 2002, Sosa et al. 2010). According to a study of a burned forest in central Chile, the rapid recovery of gramineousherbaceous and shrub cover resulted in a greater abundance of granivores (Perfetti-Bolaño et al. 2013). One year after a fire, the abundance of granivorous species was more than double that found the following year, suggesting that some species respond to short-term increases in seed availability after a fire (Smucker et al. 2005). For foliage feeders, our results differ from those reported by Dieni and Anderson (1999) and Grigera and Pavic (2007) who attributed the decrease in their density in post-fire sites to the reduction in horizontal and vertical foliage cover. A possible explanation for the increase in density we found in all the burned sites could lie on the effect of the White-crested Elaenia (Elaenia albiceps) on our results. White-crested Elaenia, a Neotropical austral migrant, is the most abundant bird species during spring and summer in the area and uses the foliage substrate for prey capture across the vertical profile (Chust et al. 2012). Large numbers of White-crested Elaenia influenced the density of foliage feeders in our study. 
It has been suggested that migratory birds may be more resilient than resident birds to disturbances such as fires (Lynch and Whigham 1995). In South American temperate forests, almost half of the bird species are either partial migrants, i.e., part of the population migrates latitudinally, $(31 \%)$ or total migrants, i.e., all the population migrates latitudinally (17\%; Cofre et al. 2007, Ibarra et al. 2017). Petit et al. (1993) found that disturbed tropical habitats tend to contain more migratory forest specialist species than undisturbed tropical forests. This agrees with our observation of a higher density of migrant birds in the most disturbed sites ("burned 2002/2015"; highly disturbed), suggesting that some burned forests may still act as habitat for migrant bird species (Smucker et al. 2005).

\section{Implications for avian conservation}

Fires are likely to occur on an even larger spatial scale and with increasing frequency and severity as a result of climate change, significantly affecting previously unburned forests (Cochrane and Schulze 1999, Peres et al. 2003). Thus, the dynamics of fire disturbance have now become a decisive factor in conservation and management of forest biodiversity. Although Chile currently lacks an adequate policy for the management of fires, national and local governments are exploring ways to prevent or at least minimize the threats posed by fires. Furthermore, Chile's policy for the protection of threatened species, such as A. araucana, demonstrates the country's will to ensure the protection of local biota. The possibility that fires allow the persistence and further recolonization of certain bird species and guilds should also be taken into account when designing post-fire management plans. This is especially important for current policies that encourage the implementation of "salvage logging" practices post-fire. Postfire management practices that affect the forest succession, e.g., planting exotic-trees and eliminating shrubs, or remove habitat legacies, e.g., harvesting standing dead trees for lumber or firewood, may be counterproductive for forest biodiversity conservation. No habitat-specialist bird or member of specialized avian guild that inhabits Chilean temperate forests has received either national or international conservation status or attention, except for C. magellanicus (Cofre et al. 2007). Furthermore, many forested areas in Chile have not been sufficiently surveyed and thus current ecological knowledge of specialized species in temperate forests is limited. Further research on how habitatspecialist species and guilds respond to fires in their population trends and productivity is needed in order to establish reliable conservation status assignments and stewardship priorities for forest biodiversity under rapid local, national, and international social-ecological changes (Ibarra et al. 2020).

Responses to this article can be read online at: https://www.ace-eco.org/issues/responses.php/1999

\section{Acknowledgments:}

We acknowledge the National Forest Service of Chile (CONAF) for logistic support and the Pewenche Quinquen Community for allowing us to work in their land. E. Gutiérrez, M. Higuera, and A. Marin provided valuable support and collaboration throughout the project. This work was supported by ANID/FONDECYT de Iniciación (11160932), Columbia University President's Global Innovation Fund, ANID/Apoyo a la Formación de Redes Internacionales entre Centros de Investigación (REDES150047), and an Internationalization Grant Agreement (PUC1566MINEDUC). We acknowledge the support from ANID PIAI BASAL FB0002, ANID/FONDAP/15110006, and the ANID Millennium Science Initiative, CESIEP Code NCS13_004. We also thank the people who supported us during fieldwork: $H$. Jaillard, C. Rivas, G. Gómez, V. Salinas, A. Contador, Z. Von Bernath, M. Rojas, X. Arangua, and P. Araneda. Two anonymous reviewers provided helpful comments on earlier drafts of the manuscript.

\section{LITERATURE CITED}

Albanesi, S., S. Dardanelli, and L. M. Bellis. 2013. Effects of fire disturbance on bird communities and species of mountain Serrano forest in central Argentina. Journal of Forest Research 19:105-114. https://doi.org/10.1007/s10310-012-0388-4

Altamirano, T. A., J. T. Ibarra, K. Martin, and C. Bonacic. 2017. The conservation value of tree decay processes as a key driver structuring tree cavity nest webs in South American temperate rainforests. Biodiversity and Conservation 26:2453-2472. https:// doi.org/10.1007/s10531-017-1369-X

Anderson, A. S., T. A. Marques, L. P. Shoo, and S. E. Williams. 2015. Detectability in audio-visual surveys of tropical rainforest birds: the influence of species, weather and habitat characteristics. PLoS ONE 10(6):e0128464. https://doi.org/10.1371/journal. pone. 0128464

Arroyo, M. T. K., L. Cavieres, A. Peñaloza, M. Riveros, and A. Faggi. 1995. Relaciones fitogeográficas y patrones regionales de riqueza de especies en la flora del bosque lluvioso templado de Sudamérica. Pages 71-100 in J. Armesto, C. Villagrán, and M. T. K. Arroyo, editors. Ecología de los bosques nativos de Chile. Editorial Universitaria, Santiago, Chile.

Barlow, J., T. Haugaasen, and C. A. Peres. 2002. Effects of ground fires on understorey bird assemblages in Amazonian forests. Biological Conservation 105(2):157-169. https://doi.org/10.1016/ S0006-3207(01)00177-X

Barlow, J., and C. A. Peres. 2004. Avifaunal responses to single and recurrent wildfires in Amazonian forests. Ecological Applications 14(5):1358-1373. https://doi.org/10.1890/03-5077

Bates, D., M. Mächler, B. Bolker, and S. Walker. 2015. Fitting linear mixed-effects models using lme4. Journal of Statistical Software 67(1):1-48. https://doi.org/10.18637/jss.v067.i01

Bibby, C. J., N. D. Burgess, D. A. Hill, and S. H. Mustoe. 2000. Bird census techniques. Second edition. Academic, San Diego, California, USA.

Bock, C. E., M. Raphael, and J. H. Bock. 1978. Changing avian community structure during early post-fire succession in the Sierra Nevada. Wilson Bulletin 90(1):119-123. [online] URL: https://www.jstor.org/stable/4161028

Bond, W. J., F. I. Woodward, and G. F. Midgley. 2005. The global distribution of ecosystems in a world without fire. New 
Phytologist 165(2):525-538. https://doi.org/10.1111/ j.1469-8137.2004.01252.x

Brown, J. K. 1995. Fire regimes and their relevance to ecosystem management. Pages 171-178 in Proceedings of the 1994 Society of American Foresters Annual Convention, 18-22 September 1994, Anchorage, Alaska, USA. Society of American Foresters, Bethesda, Maryland, USA.

Buckland, S. T., D. R. Anderson, K. P. Burnham, J. L. Laake, D. L. Borchers, and L. Thomas. 2001. Introduction to distance sampling: estimating abundance of biological populations. Oxford University Press, Oxford, UK.

Burnham, K. P., and D. R. Anderson. 2002. Model selection and inference: a practical information-theoretic approach. Second edition. Springer-Verlag, New York, New York, USA.

Catford, J. A., C. C. Daehler, H. T. Murphy, A. W. Sheppard, B. D. Hardesty, D. A. Westcott, M. Rejmánek, P. J. Bellingham, J. Pergl, C. C. Horvitz, and P. E. Hulme. 2012. The intermediate disturbance hypothesis and plant invasions: implications for species richness and management. Perspectives in Plant Ecology, Evolution and Systematics 14(3):231-241. https://doi.org/10.1016/ j.ppees.2011.12.002

Caviedes, J., and J. T. Ibarra. 2017. Influence of anthropogenic disturbances on stand structural complexity in Andean temperate forests: implications for managing key habitat for biodiversity. PLoS ONE 12(3):e0174147. https://doi.org/10.1371/journal. pone. 0169450

Chandler, R. 2014. Distance sampling analysis in unmarked.

Chavardés, R. D. 2014. Fire history and climate-fire relations in Jasper National Park, Aberta, Canada. Dissertation. University of British Columbia, Vancouver, British Columbia, Canada. [online] URL: http://hdl.handle.net/2429/46413

Chust, L., V. R. Cueto, C. G. Navarro, and S. P. Bravo. 2012. Comportamiento de alimentación y selección de microhábitats por el fiofío silbón (Elaenia albiceps chilensis) en bosques de la patagonia. Ornitologia Neotropical 23(3):313-323. [online] URL: https://sora.unm.edu/node/133317

Clarke, R. H., R. L. Boulton, and M. F. Clarke. 2005. Estimating population size of the Black-eared Miner, with an assessment of landscape-scale habitat requirements. Pacific Conservation Biology 11(3):174-188. https://doi.org/10.1071/PC050174

Clavero, M., L. Brotons, and S. Herrando. 2011. Bird community specialization, bird conservation and disturbance: the role of wildfires. Journal of Animal Ecology 80(1):128-136. https://doi. org/10.1111/j.1365-2656.2010.01748.x

Cochrane, M. A., and C. P. Barber. 2009. Climate change, human land use and future fires in the Amazon. Global Change Biology 15(3):601-612.https://doi.org/10.1111/j.1365-2486.2008.01786.x

Cochrane M. A., and M. D. Schulze. 1999. Fire as a recurrent event in tropical forests of the eastern Amazon: effects on forest structure, biomass, and species composition. Biotropica 31 (1):2-16. https://doi.org/10.1111/j.1744-7429.1999.tb00112.x

Cofre, H. L., K. Böhning-Gaese, and P. A. Marquet. 2007. Rarity in Chilean forest birds: which ecological and life-history traits matter? Diversity and Distributions 13(2):203-212. https://doi. org/10.1111/j.1472-4642.2006.00312.x

Corporación Nacional Forestal (CONAF). 2017. Análisis de la afectación y severidad de los incendios forestales ocurridos en enero y febrero de 2017 sobre los usos de suelo y los ecosistemas naturales presentes entre las regiones de Coquimbo y $\mathrm{La}$ Araucanía del sur de Chile. Technical Report. CONAF, Santiago, Chile. [online] URL: https://www.conaf.cl/tormenta_de_fuego-2017/ INFORME-AFECTACION-Y_SEVERIDAD-DE-INCENDIOSFORESTALES-VERANO-2017-SOBRE-ECOSISTEMASVEGETACIONALES-CONAF.pdf

Connell, J. 1978. Diversity in tropical rain forests and coral reefs. Science 199(4335):1302-1310. https://doi.org/10.1126/science.199.4335.1302

Dainese, M., and L. Poldini. 2012. Plant and animal diversity in a region of the Southern Alps: the role of environmental and spatial processes. Landscape Ecology 27:417-431. https://doi. org/10.1007/s10980-011-9687-y

DeBano, L. F., D. G. Neary, and P. F. Folliott. 1998. Fire's effects on ecosystems. John Wiley and Sons, New York, New York, USA.

Díaz, I. A., J. J. Armesto, S. Reid, K. E. Sieving, and M. F. Willson. 2005. Linking forest structure and composition: avian diversity in successional forests of Chiloé Island, Chile. Biological Conservation 123(1):91-101. https://doi.org/10.1016/j.biocon.2004.10.011

Dieni, J., and S. Anderson. 1999. Effects of recent burning on breeding bird community structure in aspen forests. Journal of Field Ornithology 70:491-503. [online] URL: https://www.jstor. org/stable/4514442

Donoso, C. 1993. Bosques templados de Chile y Argentina. Variación, Estructura y Dinámica. Editorial Universitaria S.A., Santiago, Chile.

Drapeau, P., M.-A. Villard, A. Leduc, and S. J. Hannon. 2016. Natural disturbance regimes as templates for the response of bird species assemblages to contemporary forest management. Diversity and Distributions 22(4):385-399. https://doi.org/10.1111/ ddi. 12407

Driscoll, D. A., D. B. Lindenmayer, A. F. Bennett, M. Bode, R. A. Bradstock, G. J. Cary, M. F. Clarke N. Dexter, R. Fensham, G. Friend, M. Gill, S. James, G. Kay, D. A. Keith, C. MacGregor, J. Russell-Smith, D. Salt, J. E. M. Watson, R. J. Williams, and A. York. 2010. Fire management for biodiversity conservation: key research questions and our capacity to answer them. Biological Conservation 143(9):1928-1939. https://doi.org/10.1016/j.

biocon.2010.05.026

Flannigan, M., B. Stocks, M. Turestsky, and M. Wotton. 2009. Impacts of climate change on fire activity and fire management in the circumboreal forest. Global Change Biology 15(3):549-560. https://doi.org/10.1111/j.1365-2486.2008.01660.x

Fontaine, J. B., D. C. Donato, W. D. Robinson, B. E. Law, and J. B. Kauffman. 2009. Bird communities following high-severity fire: response to single and repeat fires in a mixed-evergreen forest, Oregon, USA. Forest Ecology and Management 257 (6):1496-1504. https://doi.org/10.1016/j.foreco.2008.12.030 
Fox, J. W. 2013. The intermediate disturbance hypothesis should be abandoned. Trends in Ecology \& Evolution 28(2):86-92. https://doi.org/10.1016/j.tree.2012.08.014

Franklin, J. F., D. Lindenmayer, J. M. MacMahon, A. McKee, J. Magnusson, D. A. Perry, R. Waide, and D. Foster. 2000. Threads of continuity: ecosystem disturbances, biological legacies and ecosystem recovery. Conservation in Practice 1(1):8-17. https:// doi.org/10.1111/j.1526-4629.2000.tb00155.x

Fuentes-Ramírez, C. Andres Salas-Eljatib, M. E. González, J. Urrutia-Estrada, P. Arroyo-Vargas, and P. Santibañez. 2020. Initial response of understory vegetation and tree regeneration to a mixed-severity fire in old-growth. Applied Vegetation Science 23(2):210-222. https://doi.org/10.1111/avsc.12479

Fuentes-Ramírez, A., P. Arroyo-Vargas, A. del Fierro, and F. Pérez. 2019. Post-fire response of Araucaria araucana (Molina) K. Koch: assessment of vegetative resprouting, seed production and germination. Gayana Botánica 76(1):119-122. https://doi. org/10.4067/S0717-66432019000100119

Fuentes-Ramírez, A., M. Barrientos, L. Almonacid, C. Arriagada-Escamilla, and C. Salas-Eljatib. 2018. Short-term response of soil microorganisms, nutrients and plant recovery in fire-affected Araucaria araucana forests. Applied Soil Ecology 131:99-106. https://doi.org/10.1016/j.apsoil.2018.08.010

Ganey, J. L., W. M. Block, and P. F. Boucher. 1996. Effects of fire on birds in Madrean forests and woodlands. Pages 146-154 in P. F. Ffolliott, L. F. DeBano, M. B. Baker, G. J. Gottfried, G. SolisGarza, C. B. Edminster, D. G. Neary, L. S. Allen, and R.H. Hamre, tech coordinators. Effects of fire on Madrean Province Ecosystems: a symposium proceedings, March 11-15, Tucson, AZ. Gen. Tech. Rep. RM-GTR-289. Rocky Mountain Forest and Range Experiment Station, U.S. Forest Service, Fort Collins, Colorado, USA. https://doi.org/10.2737/RM-GTR-289

González, M. E., A. Lara, R. Urrutia, and J. Bosnich. 2011. Cambio climático y su impacto potencial en la ocurrencia de incendios forestales en la zona centro-sur de Chile $\left(33^{\circ}-42^{\circ} \mathrm{S}\right)$. Bosque 32(3):215-219. https://doi.org/10.4067/S0717-92002011000300002

González, M. E., T. T. Veblen, and J. S. Sibold. 2005. Fire history of Araucaria-Nothofagus forests in Villarrica National Park, Chile. Journal of Biogeography 32(7):1187-1202. https://doi. org/10.1111/j.1365-2699.2005.01262.X

González, M. E., T. T. Veblen, and J. S. Sibold. 2010. Influence of fire severity on stand development of Araucaria araucanaNothofagus pumilio stands in the Andean cordillera of southcentral Chile. Austral Ecology 35(6):597-615. https://doi. org/10.1111/j.1442-9993.2009.02064.X

González, M. E., T. T. Veblen, and J. Sibold. 2009. Wildfires in Andean Araucaria-Nothofagus forests: historical variability and ecological role. Page 158 in 10th International Congress of Ecology (INTECOL), Ecology in a Changing Climate, Brisbane, Australia.

Grigera, D., and C. Pavic. 2007. Ensambles de aves en un sitio quemado y en un sitio no alterado en un área forestal. Hornero 22(1):29-37.
Hannon, S. J., and P. Drapeau. 2005. Bird responses to burning and logging in the boreal forest of Canada. Studies in Avian Biology 30:97-115.

Harvey, B. J., D. C. Donato, and M. G. Turner. 2016. Burn me twice, shame on who? Interactions between successive forest fires across a temperate mountain region. Ecology 97:2272-2282. https://doi.org/10.1002/ecy.1439

Hidasi-Neto, J., J. Barlow, and M. V. Cianciaruso. 2012. Bird functional diversity and wildfires in the Amazon: the role of forest structure. Animal Conservation 15(4):407-415. https://doi. org/10.1111/j.1469-1795.2012.00528.x

Ibarra, J. T., K. L. Cockle, T. A. Altamirano, Y. van der Hoek, S. Simard, C. Bonacic, and K. Martin. 2020. Nurturing resilient forest biodiversity: nest webs as complex adaptive systems. Ecology and Society 25(2):27. https://doi.org/10.5751/ES-11590-250227

Ibarra, J. T., N. Gálvez, T. A. Altamirano, J. Caviedes, I. M. Rojas, C. Bonacic, and K. Martin. 2017. Seasonal dynamics of avian guilds inside and outside core protected areas in an Andean Biosphere Reserve of southern Chile. Bird Study 64(3):410-420. https://doi.org/10.1080/00063657.2017.1368447

Ibarra, J. T., and K. Martin. 2015a. Beyond species richness: an empirical test of top predators as surrogates for functional diversity and endemism. Ecosphere 6(8):1-15. https://doi. org/10.1890/ES15-00207.1

Ibarra, J. T., and K. Martin. 2015b. Biotic homogenization: loss of avian functional richness and habitat specialists in disturbed Andean temperate forests. Biological Conservation 192:418-427. https://doi.org/10.1016/j.biocon.2015.11.008

Ibarra, J. T., K. Martin, T. A. Altamirano, F. H. Vargas, and C. Bonacic. 2014. Factors associated with the detectability of owls in South American temperate forests: implications for nocturnal raptor monitoring. Journal of Wildlife Management 78 (6):1078-1086. https://doi.org/10.1002/jwmg.740

Izhaki, I., and M. Adar. 1997. The effects of post-fire management on bird community succession. International Journal of Wildland Fire 7(4):335-342. https://doi.org/10.1071/ WF9970335

Jaksic, F. M., and J. M. Fariña. 2015. Incendios, sucesión y restauración ecológica en contexto. Anales del Instituto de la Patagonia 43(1):23-34. https://doi.org/10.4067/S0718-686X2015000100003

Jaksic, F. M., and P. Feinsinger. 1991. Bird assemblages in temperate forest of North and South America: a comparison of diversity, dynamics, guild structure, and resource use. Revista Chilena de Historia Natural 64:491-510. [online] URL: http:// rchn.biologiachile.cl/pdfs/1991/3/Jaksic_\&_Feinsinger_1991.pdf

Keeley, J. E. 2009. Fire intensity, fire severity and burn severity: a brief review and suggested usage. International Journal of Wildland Fire 18(1):116-126. https://doi.org/10.1071/WF07049

Krebs, P., G. B. Pezzatti, S. Mazzoleni, L. M. Talbot, and M. Conedera. 2010. Fire regime: history and definition of a key concept in disturbance ecology. Theory in Biosciences 129:53-69. https://doi.org/10.1007/s12064-010-0082-Z 
Kotliar, N. B., S. J. Hejl, R. L. Hutto, V. A. Saab, C. P. Melcher, and M. E. McFadzen. 2002. Effects of fire and post-fire salvage logging on avian communities in conifer-dominated forests of the western United States. Studies in Avian Biology 25:49-64.

Kreisel, K., and S. Stein. 1999. Bird use of burned and unburned coniferous forest during winter. Wilson Bulletin 111:243-250.

Lara, A., S. Fraver, J. C. Aravena and A. Wolodarsky-Franke. 1999. Fire and dynamics of Fitzroya cupressoides (alerce) forests of Chile's cordillera Pelada. Ecoscience 6(1):100-109. https://doi. org/10.1080/11956860.1999.11952199

Latif, Q. S., J. S. Sanderlin, V. A. Saab, W. M. Block, and J. G. Dudley. 2016. Avian relationships with wildfire at two dry forest locations with different historical fire regimes. Ecosphere 7 (5):1-22. https://doi.org/10.1002/ecs2.1346

Lindenmayer, D. B., J. T. Wood, R. B. Cunningham, C. MacGregor, M. Crane, D. Michael, R. Montague-Drake, D. Brown, R. Muntz, and A. M. Gill. 2008. Testing hypotheses associated with bird responses to wildfire. Ecological Applications 18(8):1967-1983. https://doi.org/10.1890/07-1943.1

Luebert, F., and P. Pliscoff. 2006. Sinopsis bioclimática y vegetacional de Chile. Editorial Universitaria, Santiago, Chile.

Lynch, J., F., and D. F. Whigham. 1995. The role of habitat disturbance in the ecology of overwintering migratory birds in the Yucatan Peninsula. Pages 199-214 in S. Sader, M. Wilson, and A. Estrada, editors. Conservation of neotropical migratory birds in Mexico. Maine Agricultural and Forest Experiment Station, Orono, Maine, USA.

MacArthur, R. H., and J. W. MacArthur. 1961. On birds species diversity. Ecology 42(3):594-598. https://doi.org/10.2307/1932254

Maclean, I. M. D., M. Hassall, R. Boar, and O. Nasirwa. 2003. Effects of habitat degradation on avian guilds in East African papyrus Cyperus papyrus swamps. Bird Conservation International 13(4):283-297. https://doi.org/10.1017/S0959270903003216

Mazerolle, M. J. 2017. AICcmodavg: model selection and multimodel inference based on (Q)AIC(c). R Package version 21-1.

Milesi, F. A., L. Marone, J. Lopez de Casenave, V. R. Cueto, and E. T. Mezquida. 2002. Gremios de manejo como indicadores de las condiciones del ambiente: un estudio de caso con aves y perturbaciones del hábitat en el Monte central, Argentina. Ecología Austral 12:149-161. [online] URL: https://bibliotecadigital. exactas.uba.ar/download/ecologiaaustral/ecologiaaustral_v012_n02_p149. pdf

Moreira, F., A. Delgado, S. Ferreira, R. Borralho, N. Oliveira, M. Inácio, J. S. Silva, and F. Rego. 2003. Effects of prescribed fire on vegetation structure and breeding birds in young Pinus pinaster stands of northern Portugal. Forest Ecology and Management 184(1-3):225-237. https://doi.org/10.1016/S0378-1127(03)00214-7

Morissette, J. L., T. P. Cobb, R. M. Brigham, and P. C. James. 2002. The response of boreal forest songbird communities to fire and post-fire harvesting. Canadian Journal of Forest Research 32(12):2169-2183. https://doi.org/10.1139/x02-134
Nappi, A., and P. Drapeau. 2009. Reproductive success of the Black-backed Woodpecker (Picoides arcticus) in burned boreal forests: are burns source habitats? Biological Conservation 142 (7):1381-1391. https://doi.org/10.1016/j.biocon.2009.01.022

Peres, C. A., J. Barlow, and T. Haugaasen. 2003. Vertebrate responses to surface wildfires in a central Amazonian forest. Oryx 37(1):97-109. https://doi.org/10.1017/S0030605303000188

Perfetti-Bolaño, A., D. González-Acuña, C. Barrientos, and L. Moreno. 2013. Efectos del fuego sobre la avifauna del cerro Cayumanque, Región del Bío-Bío, Chile. Boletín Chileno de Ornitología 19(1-2):1-11. [online] URL: http://www.aveschile.cl/ wp-content/uploads/2019/03/01-11_Perfetti-Bol..pdf

Petit, D. R., J. F. Lynch, R. L. Hutto, J. G. Blake, and R. B. Waide. 1993. Management and conservation of migratory landbirds overwintering in the neotropics. Pages 70-92 in M. D. Finch and W. P. Stangel, editors. Status and management of neotropical migratory birds, Estes Park, Colorado. Technical report RM-229. Rocky Mountain Forest and Range Experiment Station, U.S. Forest Service, Fort Collins, Colorado, USA. https://doi. org/10.2737/RM-GTR-229

Pinheiro, J., D. Bates, S. Deb-Roy, D. Sarkar, S. Heisterkamp, and B. Van Willigen. 2017. nlme: linear and nonlinear mixed effects models. R Packag. Third edition. [online] URL: https://cran.rproject.org/web/packages/nlme/nlme.pdf

Pons, P., and M. Clavero. 2010. Bird responses to fire severity and time since fire in managed mountain rangelands. Animal Conservation 13(3):294-305. https://doi.org/10.1111/

j.1469-1795.2009.00337.x

Prichard, S. J., C. S. Stevens-Rumann, and P. F. Hessburg. 2017. Tamm Review: shifting global fire regimes: lessons from reburns and research needs. Forest Ecology and Management 396:217-233 https://doi.org/10.1016/j.foreco.2017.03.035

R Development Core Team. 2019. R: a language and environment for statistical computing. $\mathrm{R}$ Foundation for Statistical Computing, Vienna, Austria.

Ralph, C. J., G. R. Geupel, P. Pyle, T. E. Martin, D. F. De Sante, and B. Milá. 1996. Manual de m\%eacute;todos de campo para el monitoreo de aves terrestres. Gen. Tech. Rep. PSW-GTR-159. Pacific Southwest Research Station, U.S. Forest Service, Albany, California, USA. https://doi.org/10.2737/PSW-GTR-159

Randerson, J. T., Y. Chen, G. R. Van Der Werf, B. M. Rogers, and D. C. Morton. 2012. Global burned area and biomass burning emissions from small fires. Journal of Geophysical Research Biogeosciences 117:G04012. https://doi.org/10.1029/2012JG002128

Recher, H. F. 1969. Bird species diversity and habitat diversity in Australia and North America. American Naturalist 103 (292):75-121. https://doi.org/10.1086/282583

Reid, S., I. A. Díaz, J. J. Armesto, and M. F. Willson. 2004. Importance of native bamboo for understory birds in Chilean temperate forests. Auk 121(2):515-525. https://doi.org/10.1093/ auk/121.2.515

Royle, J. A., D. K. Dawson, and S. Bates. 2004. Modeling abundance effects in distance sampling. Ecology 85(6):1591-1597. https://doi.org/10.1890/03-3127 
Shiel, D., and F. R. Burslem. 2003. Disturbing hypotheses in tropical forests. Trends in Ecology \& Evolution 18(1):18-26. https://doi.org/10.1016/S0169-5347(02)00005-8

Simberloff, D., and T. Dayan. 1991. The guild concept and the structure of ecological communities. Annual Review of Ecology, Evolution, and Systematics 22:115-143. https://doi.org/10.1146/ annurev.es.22.110191.000555

Smucker, K. M., R. L. Hutto, and B. M. Steele. 2005. Changes in bird abundance after wildfire: importance of fire severity and time since fire. Ecological Applications 15(5):1535-1549. https://doi. org/10.1890/04-1353

Sosa, R., V. Benz, J. Galea, and I. Poggio. 2010. Efecto del grado de disturbio sobre el ensamble de aves en la reserva provincial Parque Luro, La Pampa, Argentina. Revista de la asociación Argentina de Ecología de Paisajes 1:101-110.

Stephens, J. L., I. J. Ausprey, N. E. Seavy, and J. D. Alexander. 2015. Fire severity affects mixed broadleaf-conifer forest bird communities: results for 9 years following fire. Condor 117 (3):430-446. https://doi.org/10.1650/CONDOR-14-58.1

UNESCO. 2010. World network of biosphere reserves (WNBR). Ecological Sciences for Sustainable Development, UNESCO, Paris, France. [online] URL: https://en.unesco.org/biosphere/ wnbr

Urrutia-Estrada, J., A. Fuentes-Ramírez, and E. Hauenstein. 2018. Diferencias en la composición florística en bosques de Araucaria-Nothofagus afectados por distintas severidades de fuego. Gayana Botánica 75(2):12-25. https://doi.org/10.4067/ S0717-66432018000200625

Venegas, A., S. Varela, and C. F. Estades. 2009. Efecto del fuego en la comunidad de aves de bosque en la Reserva Nacional Malleco. Boletín Chileno de Ornitología 15:1-7.

Vergara, P. M., G. E. Soto, D. Moreira-Arce, A. D. Rodewald, L. O. Meneses, and C. G. Pérez-Hernández. 2016. Foraging behaviour in Magellanic Woodpeckers is consistent with a multiscale assessment of tree quality. PLoS ONE 11(7):e0159096. https://doi.org/10.1371/journal.pone.0159096

Vierling, K., and L. Lentile. 2008. Indirect effects of fire severity on avian communities in ponderosa pine and aspen forests in western North America: a review. Fire Ecology 4:133-149. https:// doi.org/10.4996/fireecology.0402133

Vuilleumier, F. 1985. Forest birds of Patagonia: ecological geography, speciation, endemism, and faunal history. Ornithological Monographs 36:255-304. https://doi.org/10.2307/40168287

Watson, S. J., R. S. Tylor, D. G. Nimmo, L. T. Kelly, A. Haslem, M. F. Clarke, and A. F. Bennett. 2012. Effects of time since fire on birds: how informative are generalized fire response curves for conservation management? Ecological Applications 22 (2):685-696. https://doi.org/10.1890/11-0850.1

Whelan, R. J., L. Rodgerson, C. R. Dickman, and E. F. Sutherland. 2002. Critical life cycles of plants and animals: developing a process-based understanding of population changes in fire-prone landscapes. Pages 94-124 in R. A. Bradstock, J. E. Williams, and A. M. Gill, editors. Flammable Australia: the fire regimes and biodiversity of a continent. Cambridge University Press, Cambridge, UK.

White, A. M., P. N. Manley, G. L. Tarbill, T. W. Richardson, R. E Russell, H. D. Safford, and S. Z. Dobrowski. 2016. Avian community responses to post-fire forest structure: implications for fire management in mixed conifer forests. Animal Conservation 19(3):256-264. https://doi.org/10.1111/acv.12237

Wiebe, K. 2014. Responses of cavity-nesting birds to fire: testing a general model with data from the Northern Flicker. Ecology 95 (9):2537-2547. https://doi.org/10.1890/13-1711.1

Wunderle, J. M. 1997. The role of animal seed dispersal in accelerating native forest regeneration on degraded tropical lands. Forest Ecology and Management 99(1-2):223-235. https://doi. org/10.1016/S0378-1127(97)00208-9

Zúñiga, A. H., J. R. Rau, F. M. Jaksic, P. M. Vergara, F. EncinaMontoya, and A. Fuentes-Ramírez. 2021. Rodent assemblage composition as indicator of fire severity in a protected area of south-central Chile. Austral Ecology 46(2):249-260. https://doi. org/10.1111/aec.12975
Editor-in-Chief: Alexander L.Bond Subject Editor: Pierre Drapeau
Sponsored by the Society of Canadian Ornithologists and Birds Canada

Parrainée par la Société des ornithologistes du Canada et Oiseaux Canada

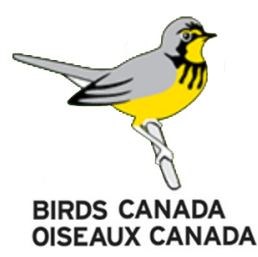


Appendix 1. Total birds observed in the four sampling sites (control, "burned 2002", "burned 2005" and "burned 2002-2015") during the 2016-2017 and 2017-2018 breeding seasons.

Name

Control

2002

Burned

Burned

(1)

$2015 \quad 2002-2015$

Patagioenas araucana

Enicognathus ferrugineus

Sephanoides sephaniodes

Veniliornis lignarius

Colaptes pitius

Campephilus magellanicus

Aphrastura spinicauda

Sylviorthorhynchus desmursii

Pygarrhichas albogularis

Pteroptochos tarnii

Scelorchilus rubecola

Scytalopus magellanicus

Elaenia albiceps

Xolmis pyrope

Colorhamphus parvirostris

Tachycineta meyeni

Troglodytes aedon

Turdus falckandii

Phrygilus patagonicus

Spinus barbata

Glaucidium nanum

Cinclodes fuscus

Cinclodes patagonicus

Callipepla californica

Zonotrichia capensis

Geranoaetus polyosoma

Anairetes parulus

Notiochelidon cyanoleuca

Upecerthia dumetaria

Megaceryle torquata

Phytotoma rara

Sicalis luteola

Phrygilus fruticeti

Agriornis livida

Leptasthenura aegithaloides
X

$\mathrm{X}$

$\mathrm{X}$

$\mathrm{X}$

$\mathrm{X}$

$\mathrm{X}$

$\mathrm{X}$

$\mathrm{X}$

$\mathrm{X}$

$\mathrm{X}$

$\mathrm{X}$

$\mathrm{X}$

$\mathrm{X}$

$\mathrm{X}$

$\mathrm{X}$

$\mathrm{X}$

$\mathrm{X}$

$\mathrm{X}$

$\mathrm{X}$

$\mathrm{X}$

$\begin{array}{lll}X & X & X \\ X & X & \\ X & & \\ X & X & \\ X & & \\ X & X & \\ X & & \\ X & X & \\ X & & \\ X & X & \\ X & X & X \\ X & X & \end{array}$

X

$\mathrm{X}$

$\mathrm{X}$

$\mathrm{X}$

$\mathrm{X}$

$\mathrm{X}$

X

$\mathrm{X}$

$X$

$X$
$X$

X X

$X \quad X$

$X \quad X$

$X \quad X$

$\mathrm{X} \quad \mathrm{X}$

$\mathrm{X}$

$\mathrm{X}$

X X

$\mathrm{X}$

X

X X

$\mathrm{X}$

X X

X X

X X

$\mathrm{X}$

$\mathrm{X}$

$\mathrm{X}$

$\mathrm{X}$

$\mathrm{X}$

X $\quad$ X 
Appendix 2. Average density per hectare for the different avian guilds, estimated using the result of the GLMM analyses. The values presented are significant in the estimate of the parameters [PE]. The standard error is shown in brackets () with estimates of $95 \%$ confidence intervals. The positive (+) and negative (-) signs indicate the direction with respect to average density in the control site.

\begin{tabular}{|c|c|c|c|c|}
\hline Avian guilds & Control & $\begin{array}{c}\text { Burned } \\
2002\end{array}$ & Burned 2015 & $\begin{array}{c}\text { Burned } 2002 \\
2015\end{array}$ \\
\hline \multicolumn{5}{|l|}{ Habitat-use } \\
\hline Shrub user & $2.8(0.05)$ & $0.24(0.06)$ & $0.23(0.06)$ & $0.53(0.05)$ \\
\hline $\begin{array}{l}\text { Vertical profile } \\
\text { generalist }\end{array}$ & $2.72(0.05)$ & $0.35(0.06)$ & $0.41(0.06)$ & \\
\hline Large-tree user & $2.82(0.08)$ & & $0.2(0.09)$ & $-0.54(0.15)$ \\
\hline Understory user & $1.68(0.05)$ & & $-0.3(0.09)$ & $-0.46(0.1)$ \\
\hline \multicolumn{5}{|l|}{ Foraging } \\
\hline Insectivorous & $3.52(0.03)$ & & & $-0.19(0.05)$ \\
\hline Granivorous & $2.1(0.07)$ & $0.57(0.08)$ & $0.68(0.08)$ & $0.88(0.08)$ \\
\hline Nectarivorous & $0.47(0.08)$ & $0.56(0.09)$ & & \\
\hline Frugivorous & $2.22(0.03)$ & $0.19(0.04)$ & & $-0.14(0.04)$ \\
\hline Herbivorous & $3.14(0.03)$ & & & $-0.17(0.05)$ \\
\hline \multicolumn{5}{|l|}{ Foraging substrate } \\
\hline Ground & $2.5(0.06)$ & $0.53(0.07)$ & $0.52(0.07)$ & $0.62(0.07)$ \\
\hline Air & $2.06(0.09)$ & $-0.33(0.16)$ & & $-0.69(0.21)$ \\
\hline Foliage & $3.02(0.04)$ & $0.39(0.05)$ & $0.29(0.054)$ & $0.17(0.06)$ \\
\hline Timber & $1.96(0.05)$ & $-0.25(0.07)$ & $-0.37(0.08)$ & $-0.87(0.12)$ \\
\hline \multicolumn{5}{|l|}{ Migratory status } \\
\hline Migrant & $3.4(0.03)$ & $0.27(0.04)$ & $0.31(0.04)$ & $0.34(0.04)$ \\
\hline Partial migrant & $2.14(0.09)$ & $0.46(0.1)$ & $0.49(0.1)$ & \\
\hline Resident & $2.2(0.06)$ & & $-0.37(0.11)$ & $-0.61(0.13)$ \\
\hline
\end{tabular}

